\title{
40 years of the UNESCO Man and the Biosphere Programme in Austria - a success story of ecologic basic research evolving into a flagship of transdisciplinarity
}

\author{
Günter Köck \& Georg Grabherr
}

Keywords: UNESCO, MAB Programme, biosphere reserve research

\section{Abstract}

In 2013 the Austrian Man and the Biosphere (MAB) research programme, funded by the Federal Ministry for Science and Research (BMWF) and coordinated by a National Committee at the Austrian Academy of Sciences (ÖAW), celebrated its $40^{\text {th }}$ anniversary this year, making it one of the longest existing national MAB committees. This article provides a short history of the international MAB programme and the Austrian MAB National Committee and highlights selected top research.

\section{The UNESCO MAB Programme}

The programme was conceived to balance biodiversity conservation, support for economic and social development and preservation of local cultural values. Key to the MAB programme are the so-called UNESCO Biosphere Reserves (BRs). BRs are ecosystems, recognized on the basis of uniform, internationally agreed criteria, where models of sustainable use of the biosphere are being developed, tested and implemented. They serve not only to protect and maintain certain ecosystems, but also to carry out ecologic research, environmentally aware land use and education for sustainable development. The global network of BRs currently includes 621 model regions in 117 countries, seven of them in Austria.

\section{History}

The MAB programme is one of the oldest and most important UNESCO research programmes dedicated to the relationship between humans and the environment and to sustainable use of natural resources. Its precursor was the UNESCO International Biological Programme (IBP), which transferred the materialfunctional ecosystem concept, developed in the 1950s by limnologists, to terrestrian ecosystems and implemented it for the first time within a globally coordinated research initiative. This was the first time that something like big biology emerged. Across the whole world, from tundra to tropical rainforests, natural examples of key ecosystems of the zonobiomes were being investigated for their material-functional components, production, energy flows and material throughputs. The IBP thus laid the foundation for today's ecosystem concept and knowledge of realized material throughput and functionalities. The problem with IBP was, however, that in an effort to obtain a total idea of the biosphere, at that time mostly natural resources were being investigated and human impact disregarded.

The Man and the Biosphere Programme was first conceived of at the 1968 biosphere conference, when, on the theme of Scientific Basis for Rational Use and Conservation of the Resources of the Biosphere, rep- resentatives from more than 60 countries debated the preservation of the basis of our livelihood. At this conference, which was organized jointly by UNESCO, the IBP and the World Conservation Union (IUCN), the term biosphere, coined by Austrian geologist Eduard Suess, a former president of the Austrian Academy of Sciences, was introduced to a wider international audience. The trail-blazing result of the conference was the first-time international recognition that protection and use of resources must go hand in hand and that interdisciplinary approaches are needed to achieve that. This makes the conference the first transnational forum to deal with sustainable development 24 years before the Rio 1992 Conference on Environment and Development (German Commission for UNESCO 2007; Köck \& Lange 2007). A resolution passed at the biosphere conference called for the establishment of an international Man and the Biosphere Research Programme. In 1970 the Man and the Biosphere Programme was agreed at the $16^{\text {th }}$ UNESCO General Conference. 1971, the year when the MAB International Coordinating Council (MAB-ICC) met for the first time, counts as the start of the programme.

At the time the MAB programme looked completely different and has evolved from initially purely ecosystematic research to a modern transdisciplinary programme. In 1971, $14 \mathrm{MAB}$ focus projects were created which continued to work more or less within the material-functional paradigm of the IBP, describing and analysing representative ecosystems, such as tropical rainforests, mountains, deserts or coastal landscapes. Quite quickly, however, it turned out that it would be difficult to integrate the results of these individual projects. Regions were needed in which to test and implement the research findings. In 1974 the famous three functions were formulated for the first time, which such areas, now called biosphere reserves (BRs), should fulfil, i. e. protection of species diversity and natural resources (protective function); education, research and dissemination (logistic support); and development of models to integrate economic development and environmental protection (development function). From 1976 onwards the first 57 BRs were 
created, yet it was still a long way from the areas designated to maintain habitats and facilitate research and long-term monitoring to become true model regions of sustainable development. The decisive push came in 1995, when the role of BRs in the $21^{\text {st }}$ century were redefined at a conference in Seville, Spain. There it was recognized that biodiversity protection could no longer be considered in isolation of human needs. Since then regional actors have been playing a key role. They are meant to live in the BRs as an integrated element and be economically active in such a way as to preserve their natural environment in the long term. A decisive factor for the successful implementation of the holistic and ambitious approach is the involvement of all local interest groups in the planning and implementation of a BR. The approach aims to turn affected people into involved people and target groups into partners (Köck \& Lange 2007). This vision, plus indicators for its implementation at global, national and regional levels, was taken up in the so-called Seville Strategy and the Statutory Framework for Biosphere Reserves (UNESCO 1996), which provided the first framework for the global network of BRs. This modern conservation and development concept was meant to facilitate the protection of valuable natural and cultural landscapes while meeting the requirements of the people living in those landscapes at the same time.

In 2008, at the World Congress of BRs in Madrid, the over ten year old BR strategy was revised and the Madrid Action Plan (MAP) 2008-2013 agreed, which was to prepare the BR network for the $21^{\text {st }}$ century by promoting research, training and capacity building, esp. in view of the challenges of global change (UNESCO 2008; Braun 2010). The MAB-ICC 2013 determined a procedure for evaluating the implementation of the MAP and for developing a future strategy for the MAB programme and the world BR network for the period 2014-2021 (UNESCO 2013). In addition, and after years of debate, a three-stage exit strategy was agreed to deal with first-generation BRs (i.e. those without three-level zoning). This was a decisive step in ensuring quality control within the global BR network, which will in the medium term only include modern, second-generation BRs.

\section{MAB in Austria}

\section{History}

In the 1960s UNESCO reacted to serious contemporary problems of dramatic increases in resource consumption and environmental degradation by establishing the MAB programme. In Austria people also became aware of the urgency of these issues and in 1973, just two years after the start of the MAB programme, the Austrian National MAB Committee was created at the Austrian Academy of Sciences (ÖAW), based on an agreement with the federal ministry of science and research and charged with the task of controlling and coordinating MAB research. Austria thus is one of the first nations to get involved in the MAB programme. The National Committee is made up of acclaimed scientists, plus representatives of ministries, federal land organizations, the Austrian UNESCO Commission and NGOs, and was endowed with a separate research budget from the start. This budget allows the Committee not just to identify research gaps but to fill them with appropriate research projects. The National Committee monitors the Austrian research scene, analyses research needs, formulates new research strategies and stimulates as well as funds research projects. The National Committee advises and supports BR managements on scientific and technical issues and provides the link to the MAB Secretariat in Paris (Köck et al. 2011).

Overall, the MAB National Committee, which is unique in the world for having its own research budget, has funded countless research projects in the four decades of its existence. To illustrate its work, a few examples are presented below.

Even in the late 1960s, Austria had been involved in the IBP with research programmes on dwarf shrub heaths on Mt. Patscherkofel (Larcher 1977) and on nival vegetation on Hoher Nebelkogel peak (Moser et al. 1978), as well as one on Neusiedler See (Löffler 1979).

Once the MAB programme had been established, Austria was one of the first states anywhere to get involved. Early MAB projects more or less continued the IBP concept and focused on describing and analysing representative ecosystems, such as alpine sedge heaths in the Central Alps or routinely monitoring lakes, such as Neusiedler See (Burgenland), Piburger See (Tyrol) and high mountain lakes in the Hohe Tauern range (Pechlaner \& Sampl 1984; Löffler \& Newrkla 1985). Results of the early MAB studies were published between 1976 and 2003 in the 19 volume series Veröffentlichungen des Österreichischen MAB-Programms. The studies produced valuable data on almost anything of ecological interest or related to the IBP research focus. A significant exception was the MAB metaproject Obergurgl, dedicated to studying the ecosystem in the municipality of Obergurgl in all its ecologic and socioeconomic components. Obergurgl should stand for a limited miniature cosmos and reflect the basic limitation of the total biosphere (Patzelt 1987).

Botanist Walter Moser (University of Innsbruck at the time) conceived and conducted the project. He succeeded in bringing together hotel owners from Obergurgl, civil servants of the Tyrolean federal state government and scientists. Together with leading systems analysts of the time from the International Institute for Applied Systems Analysis, Laxenburg (Austria) they developed a computer-aided model of systemic interactions for Obergurgl. The computer model included a vast range of ecologic and sociodemographic framework conditions, from wildlife biology to demographics, and was internationally recognized as a pioneering feat of applied, computer-aided systems analysis way ahead of its time. 
In parallel with the pioneering achievements of the Obergurgl project, other working groups strove for deeper insights and analytical-descriptive representation as laid down in the IBP concept. The MAB Hohe Tauern project started in 1975 and investigated the grassland ecosystems of the Central Alps in terms of primary production and associated processes, such as photosynthesis, breathing, transpiration, later extended to cover the ecological problems associated with ski runs (Cernusca 1977; Mayer 1990). It did not develop the socioeconomic elements of the Obergurgl model further, but the Hohe Tauern project added greatly to our knowledge of ecosystem physiology of alpine grassland ecosystems. Even so, the project was unable to control or prevent the massive expansion of skiing areas.

In 1977 the first Austrian BRs were established: Gossenköllesee and Gurgler Kamm in Tyrol, Untere Lobau in Vienna and Neusiedler See (Lake Neusiedl) in Burgenland.

Until the 1990s, MAB projects on various topics followed, for instance on the problems of letting high-mountain pastures in Salzburg go fallow (Sameralm-Projekt, Riedl 1983), or on ecosystem changes at the Altenwörth Danube dam (Grosina 1985; Hary \& Nachtnebel 1989; Parz-Gollner \& Herzig 2000). In the period between the first generation MAB projects and the implementation of the Seville Strategy a number of projects were initiated that explored different types of ecosystems but with a distinct orientation on problems. Of these the project Hemeroby of Austrian forest ecosystems and the climate impact research initiative GLORIA deserve a closer look.

\section{Hemeroby of Austrian Forest Ecosystems}

When the debate about dying forests reached its peak in the 1980s and no ecologic research institution worth its salt could afford to stay out of it, the National Committee planned a large-scale forecast study for the north-eastern Alps. At the same time, NGOs and others claimed that one cause for the scale of forest decline was inappropriate and unsustainable forestry and that there were practically no natural forests left. The National Committee decided to investigate the second of these claims. The study took 5000 concrete forest areas of the Austrian forest inventory and compared them with the potential forest vegetation (Grabherr et al. 1998). On that basis a degree of naturalness was calculated. The method corresponds to the hemeroby concept which quantifies cultural effects using biological and pedological indicators. Forestry actors first reacted with suspicion but over time with increasing acceptance. The study demonstrated that about a quarter of Austrian forests can be described as near-natural or natural. The largest share of forests was somewhat changed and about a quarter was artificial or non-natural. The forestry took these figures as proof for its sustainable use of the forest over generations. NGOs were surprised by the results, as they had gone into the debate with a notion of greater changes in the Austrian forests. With this study the Austrian MAB National Committee presented a much noted normative example of conservation research.

\section{GLORIA (The Global Research Initiative in Alpine Environments)}

The GLORIA project is also based on the MAB programme and monitors changes in summit flora in high mountain areas across the world, from Arctic mountains like the Byranga and Brooks Range to tropical mountains in South America, Africa and Southeast Asia. The GLORIA method is direct observation of changes in species, chosen for being cost-efficient, time-saving and scientifically sound. It enables working groups in developing countries to participate in a high-end research programme without needing access to expensive laboratories. In over a hundred so-called target regions observations from recent years show changes in species composition and species patters of high mountain flora. GLORIA is definitely the Austrian flagship project in climate impact monitoring and has found international acclaim (Grabherr et al. 2010; Gottfried et al. 2012; Pauli et al. 2010; Pauli et al. 2012).

In the year 2000 the first modern second generation BR was established in the Großes Walsertal (Vorarlberg), followed in 2005 by Wienerwald BR (Vienna and Lower Austria) and in 2012 by Salzburger Lungau and Kärntner Nockberge BR. In 2006 the Austrian MAB National Committee approved a catalogue of criteria for Austrian BRs, whose set of rules are binding for the designation of new BRs (Austrian MAB-NC 2006).

For the last ten years, the National Committee has focused its research increasingly on studies in and for national BRs (Köck et al. 2009a). Since 2005 some 2.25 million euros have been invested in research project. These are designed to support BR managers in fulfilling their tasks as well as using the areas as objects of basic research. In recent years, the MAB Committee has begun to fund international MAB cooperation projects with partners in Greece, the Czech republic, Germany, Italy, Ethiopia, Mexico, Columbia and Chile. These projects cover a wide range of topics, from climate change to monitoring to future-bound concepts, landscape ecology or social-science topics (Table 1). Due to the large number of projects, the table only gives a rough idea of the investigated themes.

The Austrian MAB National Committee's efforts in coordinating and developing the international MAB programme further have been widely acknowledged. An example: the Austrian MAB National Committee is the only one to date to grant additional MAB Young Scientist Awards to fund the education of young scientists from developing countries. The MAB Committee is working at both national and international level towards a solution for the first generation BRs (Köck 2011). To this end, Austria funded a meeting of experts at the UNESCO headquarters in Paris in 2011, 
Table 1 - List of selected projects funded by the Austrian MAB National Committee. Many project reports can be downloaded from http:/ / epub.oeaw.ac.at/Projektberichte. See also Fischer-Kowalski et al. 2008; Coy \& Weixlbaumer 2009; Köck et al. 2009b; Köck 2010; Borsdorf et al. 2011; Jungmeier et al. 2011; Petridis 2012; Tessema et al. 2012; Jungmeier et al. 2013 and Marchant \& Borsdorf 2013.

\begin{tabular}{|c|c|}
\hline Project title & Coordinator \\
\hline $\begin{array}{l}\text { Perspective LOBAU 2020: exploring management options of a heavily used urban BR con- } \\
\text { fronted with new urban developments in its neighbourhood considering a restricted potential } \\
\text { for ecosystem development }\end{array}$ & $\begin{array}{l}\text { A. Arnberger (University of Natural Re- } \\
\text { sources and Life Sciences, Vienna) }\end{array}$ \\
\hline $\begin{array}{l}\text { Introducing social science into Biosphere Reserve Integrated Assessment (BRIA): conceptual } \\
\text { framework and indicators }\end{array}$ & $\begin{array}{l}\text { M. Fischer-Kowalski (Institute for Social Ecol- } \\
\text { ogy, Vienna) }\end{array}$ \\
\hline $\begin{array}{l}\text { Participation processes in BRs - development of an intervention theory, analysis of strategies } \\
\text { and procedural ethics by example of BRs Nockberge, Wienerwald and Großes Walsertal } \\
\text { (Austria) }\end{array}$ & $\begin{array}{l}\text { M. Jungmeier (E.C.O. Institute of Ecology, } \\
\text { Klagenfurt) }\end{array}$ \\
\hline $\begin{array}{l}\text { BR landscapes and human health benefits: analysing the potential of Wienerwald BR on life } \\
\text { quality and psychological well-being }\end{array}$ & $\begin{array}{l}\text { B. Allex (University of Natural Resources and } \\
\text { Life Sciences, Vienna) }\end{array}$ \\
\hline Sources of air pollution in Austrian BRs & P. Seibert (University of Vienna) \\
\hline Effects of climate and land-use change in high-altitude ecosystems of Gurgler Kamm BR & B. Erschbamer (University of Innsbruck) \\
\hline $\begin{array}{l}\text { Reconciling ecological, sociological and economic interests in mountain forests case study } \\
\text { Gurgler Kamm }\end{array}$ & $\begin{array}{l}\text { R. Jandl (Federal research Centre for Forests, } \\
\text { Vienna) }\end{array}$ \\
\hline $\begin{array}{l}\text { Future development strategies for Großes Walsertal BR - a regional economic and percep- } \\
\text { tional analysis }\end{array}$ & M. Coy (University of Innsbruck) \\
\hline $\begin{array}{l}\text { Evaluating the zonation of Wienerwald BR: how well does the conservation zone contribute to } \\
\text { biodiversity conservation? }\end{array}$ & $\begin{array}{l}\text { W. Willner (VINCA-Vienna Institute for Na- } \\
\text { ture Conservation and Analyses) }\end{array}$ \\
\hline $\begin{array}{l}\text { Integrated sustainable wildlife management in Wienerwald BR. New approaches to the } \\
\text { management of conflicts between humans and wildlife }\end{array}$ & $\begin{array}{l}\text { F. Reimoser (University of Veterinary Medi- } \\
\text { cine, Vienna) }\end{array}$ \\
\hline $\begin{array}{l}\text { Monitoring biocultural diversity in Großes Walsertal BR: the use and management of biodi- } \\
\text { versity of crops, cultivars and wild gathered species }\end{array}$ & $\begin{array}{l}\text { C.R. Vogl (University of Natural Resources } \\
\text { and Life Sciences, Vienna) }\end{array}$ \\
\hline \multicolumn{2}{|l|}{ International cooperation } \\
\hline Advanced geophysics for the protection of the Sian Ka'an BR (Mexico) & K. Motschka (Geological Survey Austria) \\
\hline $\begin{array}{l}\text { Outlining a sustainable future for the island of Samothraki (Greece) as a MAB BR and creat- } \\
\text { ing a regional showcase }\end{array}$ & S. Singh (Institute for Social Ecology, Vienna) \\
\hline $\begin{array}{l}\text { Transboundary information exchange for revision and functional improvement of zonation in } \\
\text { Lower Morava BR (Czech Republic) }\end{array}$ & $\begin{array}{l}\text { H. Kirchmeier (E.C.O. Institute of Ecology, } \\
\text { Klagenfurt) }\end{array}$ \\
\hline BRs in Colombia - status, information and improvements & $\begin{array}{l}\text { A. Borsdorf (Institute for Interdisciplinary } \\
\text { Mountain Research, Innsbruck }\end{array}$ \\
\hline BRs in Ethiopia - preliminary study & $\begin{array}{l}\text { M. Jungmeier (E.C.O. Institute of Ecology, } \\
\text { Klagenfurt) }\end{array}$ \\
\hline
\end{tabular}

as well as promoting rezoning of the first generation BRs. Around 200000 euros were invested in research on redesigning Neusiedler See BR (Wrbka et al. 2009). At the moment it is however doubtful whether the efforts of the National Committee will be rewarded. There is quite a high probability that Austria will lose up to four BRs within the next two years under the rules of the exit strategy, but at least the quality of the remaining three BRs, which are very successful, is exceptional. The older two, Großes Walsertal and Wienerwald BR, are seen as proper model regions for sustainable development and are recognized internationally as ideal types of a BR.

The National Committee also produces acclaimed books, e. g. the white paper of Austrian BRs, Inspired by Diversity (Lange 2005), the award-winning volume on Austrian environmental research, Planet Austria (Köck et al. 2009b), the Austrian contribution to the $40^{\text {th }}$ anniversary of the international MAB programme, Biosphere Reserves in the Mountains of the World: Excellence in the Clouds? (Austrian MAB-NC 2011), as well as the cookbook of Austrian BRs, Vielfalt genießen - $A$ Connoisseur's World, which also won an award (Köck et al. 2011; Köck et al. 2013).

\section{Summary}

Over the last 40 years, the Austrian National Committee has not only produced exceptional research but also been closely involved from the start in coordinating and further developing the international MAB programme. The dedication of the National Committee within the international MAB family is being recognized abroad. For three periods in a row, Austrian representative Günter Köck was elected deputy chair of the international MAB programme. Nationally he is the coordinator of the Austrian Academy of Sciences research programmes. The National Committee aims to continue its involvement in the future of this UNESCO success story within its personal and financial scope. Recently it approved six new research projects in Austrian BRs. At a time when climate conferences stumble from one minimum compromise to the next, programmes like Man and the Biosphere are more important than ever. With its global network of BRs as internationally linked sites of research and education, it does not just propose sustainable handling of the environment but studies it and presents solutions. 


\section{References}

Austrian MAB-NC 2006. National Criteria for Biosphere Reserves in Austria. In: Österreichische Akademie der Wissenschaften - MAB-Nationalkomitee (ed.), Erhalt der biologischen und kulturellen Vielfalt. Modelle für nachbaltige Entwick.lungsstrategien im 21. Jabhundert. Orte der Forschung, Bildung und Umweltbeobachtung. Available at: http://epub.oeaw.ac.at/0xc1aa500d_0x0011e796.

Austrian MAB-NC 2011. Austrian MAB Committee (ed.), Biosphere Reserves in the Mountains of the WorldExcellence in the Clouds?

Borsdorf, A., F. Borsdorf \& L.A. Ortega 2011. Towards climate change adaptation, sustainable development and conflict resolution - the Cinturón Andino Biosphere Reserve in Southern Colombia. eco.mont 3 (2): 43-48.

Braun, V. 2010. Research concepts in protected areas in the Alps. eco.mont 2 (2): 55-60.

Cernusca, A. 1977. Alpine Grasheide Hohe Tauern. Ergebnisse der Ökosystemstudie 1976. Veröffentlichungen des Österreichischen MAB-Programms. Band 1. Innsbruck.

Coy, M. \& N. Weixlbaumer 2009. Der Biosphärenpark als regionales Leitinstrument. Das Große Walsertal im Spiegel der Nutzer. alpine space - man \& environment. Volume 10. Innsbruck.

Fischer-Kowalski M., K.-H. Erb \& S.J. Singh 2008. Extending BRIM to BRIA: Social mentoring and integrated sustainability assessment. In: Chmielewski, T. (ed.), Nature conservation management: From idea to practical results: 208-219.

German Commission for UNESCO 2007. UNESCO Biosphere Reserves: Model regions with a Global Reputation. UNESCO today 2: 13-15.

Gottfried, M., H. Pauli, A. Futschik, M. Akhalkatsi, P. Barancok, J.L.B. Alonso, G. Coldea, J. Dick, B. Erschbamer, M.R. Fernández Calzado, G. Kazakis, J. Krajci, P. Larsson, M. Mallaun, O. Michelsen, D. Moiseev, P. Moiseev, U. Molau, A. Merzouki, L. Nagy, G. Nakhutsrishvili, B. Pedersen, G. Pelino, M. Puscas, G. Rossi, A. Stanisci, J.-P. Theurillat, M. Tomaselli, L. Villar, P. Vittoz, I. Vogiatzakis \& G. Grabherr 2012. Continent-wide response of mountain vegetation to climate change. Nature Climate Change 2: 111-115.

Grabherr G., G. Koch, H. Kirchmeier \& K. Reiter 1998. Hemerobie österreichischer Waldökosysteme. Veröffentlichungen des Österreichischen MaB-Programms. Band 17. Innsbruck.

Grabherr, G., H. Pauli \& M. Gottfried 2010. A worldwide observation of effects of climate change on mountain ecosystems. In: Borsdorf, A., G. Grabherr, K. Heinrich, B. Scott \& J. Stötter (eds.), Challenges for Mountain Regions - Tackling Complexity: 48-57

Grosina, H. 1985. Vorstudie für das Forschungsobjekt „Ökosystemstudie Donaustau“. Veröffentlichungen des Österreichischen MaB-Programms. Band 11. Innsbruck.

Hary, N. \& H.-P. Nachtnebel 1989. Ökosystemstudie Donaustau Altenwörth. Veränderungen durch das Donaukraftwerk Altenwörth. Veröffentlichungen des Österreichischen MaB-Programms. Band 14. Innsbruck.

Jungmeier, M., I. Paul-Horn, D. Zoller, F. Borsdorf, K. Grasenick, S. Lange \& B. Reutz-Hornsteiner 2011. Biosphere reserves as a long-term intervention in a region - strategies, processes, topics and principles of different participative planning and management regimes of biosphere reserves. eco.mont 3 (1): 29-36.

Jungmeier M., T. Köstl, S. Lange \& M. Bliem 2013. The art of omission: BRIM Nockberge - design of a biosphere integrated monitoring for the Carinthian part of the Biosphere Reserve Salzburger Lungau \& Kärtner Nockberge. eco.mont 5 (2): 15-22.

Köck, G. \& S. Lange 2007. UNESCO biosphere parks in Austria - model regions for sustainable development. Perspektiven 7: 14-18.

Köck, G., G. Koch \& C. Diry 2009a. The UNESCO Biosphere Reserve „Biosphärenpark Wienerwald“ (Vienna Woods) - a Long History of Conservation. eco.mont 1 (1): 51-56.

Köck, G., L. Lammerhuber \& W.E. Piller 2009b. Planet Austria: Stein - Wasser - Leben. Available at: http://planet-austria.at/

Köck, G. 2010. Mountain and global change research programmes in Austria In: Borsdorf, A., G. Grabherr, K. Heinrich, B. Scott \& J. Stötter (eds.), Challenges for Mountain Regions - Tackling Complexity: 16-19.

Köck, G. 2011. A new Label for Biosphere Reserves with a Long Research Tradition? The Case Study of the Gossenköllesee BR, Austria. In: Austrian MAB Committee (ed.), Biosphere Reserves in the Mountains of the World-Excellence in the Clouds? 60-63.

Köck, G., L. Lammerhuber \& M. Umhack 2011. Vielfalt genießen - Das Kochbuch der österreichischen Biosphärenparks (A Connoisseur's World - The Austrian Biosphere Reserves).

Köck, G., M. Umhack \& C. Diry 2013. The Austrian Biosphere Reserves. A (connoisseur's) world beyond the cookery book. eco.mont 5 (2): 59-63.

Lange, S. 2005. Inspired by diversity. Available at: http:/ / epub.oeaw.ac.at/3596-3inhalt

Lange, S. 2011. Biosphere Reserves in the mountains of the world and their standing after 40 years of UNESCO's MAB Programme. eco.mont 3 (1): 55-58.

Larcher, W. 1977. Ergebnisse des IBP-Projekts ,Zwergstrauchbeide Patscherkofel". Sitzungsbericht Österreichische Akademie der Wissenschaften, mathematisch-naturwissenschaftliche Klasse. Abteilung I, Wien. 186 (6-10): 310371.

Löffler, H. 1979. Neusiedlersee: the limnology of a shallow lake in central Europe. Monographiae Biologicae. Volume 37.

Löffler, H. \& P. Newrkla 1985. Der Einfluss des diffusen Nährstoffeintrags auf die Eutrophierung von Seen. Teil 2: Neusiedlersee, Attersee. Veröffentlichungen des Österreichischen MAB-Programms. Band 8. Innsbruck. 
Marchant, C. \& A. Borsdorf 2013. Protected areas in Northern Colombia - on a track to sustainable development? eco.mont 5 (2): 5-14.

Mayer, H. 1990. Schipistenökologische Umweltverträglichkeitsprüfung der Wald-Abfahrten im Gasteiner Schi-Zirkus. Veröffentlichungen des Österreichischen MaBProgramms. Band 16. Innsbruck.

Moser, W., W. Brzoska, K. Zachhuber \& W. Larcher 1978. Ergebnisse des IBP-Projekts „Hoher Nebelkogel 3184 m“. Sitzungsbericht Österreichische Akademie der Wissenschaften, mathematisch-naturwissenschaftliche Klasse: 387-408.

Parz-Gollner, R. \& A. Herzig 2000. Ökosystemstudie Donaustau Altenwörth. Band 2. Veröffentlichungen des Österreichischen MaB-Programms. Band 18. Innsbruck.

Patzelt, G. 1987. MAB-Projekt Obergurgl. Veröffentlichungen des Österreichischen MaB-Programms. Band 10. Innsbruck.

Pauli, H. M. Gottfried, C. Klettner \& G. Grabherr 2010. Mount Schrankogel (3497 m, Stubaier Alpen, Tyrol) - the GLORIA pioneer master site. In: Borsdorf, A., G. Grabherr, K. Heinrich, B. Scott \& J. Stötter (eds.), Challenges for Mountain Regions - Tackling Complexity: 48-57.

Pauli H., M. Gottfried, S. Dullinger, O. Abdaladze, M. Akhalkatsi, J.L.B. Alonso, G. Coldea, J. Dick, B. Erschbamer, R. Fernández Calzado, D. Ghosn, J.I. Holten, R. Kanka, G. Kazakis, J. Kollár, P. Larsson, P. Moiseev, D. Moiseev, U. Molau, J. Molero Mesa, L. Nagy, G. Pelino, M. Puscas, G. Rossi, A. Stanisci, A.O. Syverhuset, J.-P. Theurillat, M. Tomaselli, P. Unterluggauer, L. Villar, P. Vittoz \& G. Grabherr 2012. Recent Plant Diversity Changes on Europe's Mountain Summits. Science 336 (6079): 353-355

Pechlaner, R. \& H. Sampl 1984. Der Einfluss des diffusen Nährstoffeintrags auf die Eutrophierung von Seen. Teil 1: Piburger See, Wörther See und Millstätter See. Veröffentlichungen des Österreichischen MAB-Programms.Band 8. Innsbruck.

Petridis, P. 2012. Perceptions, attitudes and involvement of local residents in the establishment of a Samothraki Biosphere Reserve, Greece. eco.mont 4 (1): 59-63.

Riedl, H. 1983. Die Ergebnisse des MaB-Projekts „Sameralm“. Ein Beitrag zur sozioökonomisch gesteuerten Veränderung subalpiner Landschaftssysteme. Veröffentlichungen des Österreichischen MAB-Programms.Band 5. Innsbruck.

Tessema, T.B., M. Jungmeier \& M. Huber 2012. The relocation of the village of Arkwasiye in the Simien Mountain National Park in Ethiopia: an intervention towards sustainable development? eco.mont 4 (2): 13-20.
UNESCO 1996. The Seville Strategy for Biosphere Reserves and The Statutory Framework of the World Network of Biosphere Reserves. UNESCO, Paris.

UNESCO 1998. Madrid Action Plan for Biosphere Reserves (2008-2013).

UNESCO 2013. Final report of the $25^{\text {th }}$ Session of the International Coordinating Council of the Man and the Biosphere (MAB) Programme. Available at: http:/ / www.unesco.org/new/fileadmin/MULTIMEDIA /HQ/SC/pdf/SC-13-CONF-225-11_Final_Report_ en.pdf (accessed 15/12/2013)

Wrbka, T., M. Prinz, C. Renetzeder, A. StockerKiss, C. Brandenburg \& K. Ziener 2009. Redesigning the Biosphere Reserve Neusiedler See. doi: 10.1553/rbrns

\section{Authors}

\section{Günter Köck}

studied biology at the University of Innsbruck, Austria. His extensive research focuses on biomonitoring studies of aquatic ecosystems. Since 1997 he has led projects of the Austro-Canadian research cooperation High-Arctic. In the year 2000 he was awarded the Canada Prize of the University of Innsbruck. In 2004 he became coordinator of the national and international research programmes of the Austrian Academy of Sciences. He is Secretary-General of the Austrian MAB National Committee, Vice-Chair of the UNESCO MAB Programme, and the Austrian delegate to the European Alliance of Global Change Research Committees, member of the Scientific Board of Hohe Tauern National Park, as well as one of the Austrian delegates to the International Scientific Committee for Alpine Research. In 2009 he became co-editor of eco.mont. In 2010 the Canadian Government recognized his exceptional contributions to CanadianAustrian relations by awarding him the Canadian Go for Gold honorary medal. He is author of the awardwinning books Planet Austria and The Austrian Biosphere Reserves - A Connoisseur's World.

\section{Georg Grabherr}

emeritus professor of conservation biology, vegetation and landscape ecology; founder and long-term director of the Global Observation Research Initiative in Alpine Environments (GLORIA) at the Institute for Interdisciplinary Mountain Research (IGF, Austrian Academy of Sciences); Chair of the Austrian MAB National Committee. Grabherr has published in top journals and written many books on ecosystems, ecology, biology of alpine habitats and biodiversity in Austria. He was Austrian Scientist of the Year 2012 and has received many awards. 